\title{
Winter home ranges and movements of polecats Mustela putorius in Białowieża Primeval Forest, Poland
}

\author{
Marcin BRZEZIŃSKI ${ }^{1}$, Włodzimierz JĘDRZEJEWSKI \\ and Bogumiła JĘDRZEJEWSKA ${ }^{2}$
}

\begin{abstract}
Brzeziński M., Jędrzejewski W. and Jędrzejewska B. 1992. Winter home ranges and movements of polecats Mustela putorius in Białowieża Primeval Forest, Poland. Acta theriol. 37: $181-191$.

Polecats Mustela putori $\iota s$ Linnaeus, 1758 inhabiting a $4.5-\mathrm{km}$ stretch of Orł6́wka stream in the Białowieża National Park, were studied by live-trapping in autumn and winter $1989-91$. Ten polecats (6 males and 4 females) were captured. Every winter, from 1 to 3 polecats resided on the stream, and 1 to 3 transient polecats appeared on the river for short periods. None of the captured polecats persisted on the stream for three winters. The home ranges of resident males (estimated linearly along the stream) varied from 1 to $3.05 \mathrm{~km}$, and those of females from 0.65 to $1.65 \mathrm{~km}$. The home ranges of females were exclusive, but they could be completely overlapped by male home ranges. Radio-tracking of one resident male showed that its average daily movement distance was $1.1 \mathrm{~km}$ (range $0-2.1 \mathrm{~km}$ ). During 19 days, it utilised 8 dens. Among polecats captured as pests by farmers in the village of Białowieża $(n=94)$ between 1960 and 1990, males predominated (sex ratio $1.7: 1$ ). Most individuals (54\%) were captured in the cold season (November - February). The most likely cause of their appearance in the village was due to freezing of the rivers, which deprived the polecats of access to anurans and made them search for other food sources. From March till June, almost all the animals captured were males (of large body size). Their influx to the village might have resulted from their mating strategy: nomadism in search for receptive females. Polecats caught in autumn (males and females equally numerous) had low weights. They were the young dispersing from their natal ranges. Mammal Research Institute, Polish Academy of Sciences, 17-230 Białowieża, Poland Key words: Mustela putorius, winter home ranges, live-trapping, movements, Białowieża National Park, Poland
\end{abstract}

\section{Introduction}

The polecat Mustela putorius Linnaeus, 1758 occurs almost in the whole of Europe except the extreme north and southeastern parts of the continent (review: Walton 1977, Blandford 1987). During the last 150 years, this species has been

\footnotetext{
${ }^{1}$ Present address and reprint request address: Department of Ecology, University of Warsaw, Krakowskie Przedmiescie 26/28, 00-927 Warsaw, Poland

${ }^{2}$ Present address: Workshop for Ecology and Protection of the Natural Environment, 17-230 Białowieża, Poland
} 
constantly extending its geographical range to the northeast (Kalela 1948, Danilov and Rusakov 1969, Skarén 1979) but at the same time it has disappeared from or declined in many areas in central and western Europe (Jensen and Jensen 1972, Walton 1977, Langley and Yalden 1977, Mermod et al. 1983, Libois 1984, Weber 1988, Santos-Reis 1983, Lodé 1988). There is much discussion about persecution by man and devastation of habitats as the possible causes of polecat decline (Walton 1970, Jensen and Jensen 1972, Blandford 1987, Lodé 1988, Weber 1989a). In Poland, the polecat is still a common species and occurs in most of the country (Buchalczyk 1981, 1983).

The polecat is known as a predator related to human settlements, often inhabiting farm buildings (review: Blandford 1987) and causing damage to poultry and other small farm animals (Ewer 1973, Blandford 1987).

Studies on the spatial organization of polecat populations, the utilization of home ranges and resting sites, and daily activity of these animals were carried out by Herrenschmidt (1982), Lodé (1988), Nilsson (1978) and Weber (1989a, b). However, most of that information comes from areas, which have been considerably changed by man, so we do not know to what extent they reflect the natural habits of polecats against its adaptability to man-made environment.

The Białowieża National Park, where our study was conducted, protects the remnants of the primeval lowland forests, which in the past covered a large part of continental temperate Europe. Polecats inhabiting the Park feed predominantly on anurans in autumn and winter (Jędrzejewski et al., in prep.). In this paper, we present some data (1) of the polecat territorial spacing and movements during 3 winters in the Białowieża National Park and (2) on polecats trapped by farmers in the nearby village of Białowieża since 1960. The investigations were part of a long-term project on predator-prey relationships in the Białowieża National Park that began in 1985/86 (Jędrzejewski et al. 1989, Jędrzejewski and Jędrzejewska 1992, Jędrzejewski et al. 1992).

\section{Study area}

The Białowieża National Park $\left(23^{\circ} 55^{\prime} \mathrm{E}, 52^{\circ} 45^{\prime} \mathrm{N}\right)$ covers $47.5 \mathrm{~km}^{2}$ and contains deciduous, mixed and coniferous mature forests. The Park is surrounded by the Białowieża Primeval Forest (total area $1,250 \mathrm{~km}^{2}, 580 \mathrm{~km}^{2}$ of which is in Poland and $670 \mathrm{~km}^{2}$ in Belarus Republic). The most common tree species growing in the Park are oak Quercus robur, linden Tilia cordata, hornbeam Carpinus betulus, maple Acer platanoides, pine Pinus silvestris and spruce Picea abies. The bog alderwoods (comprising mainly black alder Alnus glutinosa) are scattered in many places of the National Park and cover 6\% of its area. The riverside floodplain forest (comprising ash Fraxinus excelsior and black alder) occurs along small water-courses and covers $8.5 \%$ of the Park area. A detailed description of the forest habitats is given by Faliński (1986). The National Park is strictly preserved; cutting and hunting activities are not allowed, and penetration by man is restricted to a few tourist paths.

The data on the polecat population come from the southwestern part of the National Park. Most data were collected along the stream Orłowka and in the nearby ash-alderwoods along a stretch of 4 $-5 \mathrm{~km}$. The stream width ranges from 1 to $4 \mathrm{~m}$ and the water depth is up to $1.5 \mathrm{~m}$. In some years, the stream may dry up in late summer. In winter, it freezes when the temperature drops below $-5^{\circ} \mathrm{C}$ (upstream, nearly stagnant water) and below $-15^{\circ} \mathrm{C}$ (downstream, more rapid current). 
From the south, the National Park borders the open fields and meadows of the Białowieża Glade. In the middle of the glade, the village of Białowieża is located. Most of the buildings are small wooden houses with barns and gardens. The population of Białowieża is about 2,500.

The Białowieża National Park lies in the zone of temperate, subcontinental climate characterized by many transitional features (Olszewski 1986). The three winters studied were milder than average. Snow cover persisted for about one month in 1988/89 (in December) and 1989/90 (in November/ December), and about 2 months in 1990/91 (in January - March). The maximum depth of snow did not exceed $25 \mathrm{~cm}$ during any of the studied winters.

\section{Methods and material}

In the Białowieża National Park, polecats were captured in live-traps from January to March in 1989 and from November to April in 1989/90 and 1990/91. (The summer live-trapping conducted in 1989 proved to be unsuccessful so it was not continued during the following summers.) Wooden-box and wire-mesh traps baited with fresh fish were used. The traps were distributed along a $4-5-\mathrm{km}$ stretch of Orł6wka stream at 100 to $700-\mathrm{m}$ intervals. The number of traps operated during a trapping session varied from 4 to 18 . During a trapping session, traps were set for $3-4$ nights (rarely for 1 2 nights) and checked every $24 \mathrm{~h}$. Altogether, 16 trapping sessions yielded 551 trapnights.

Altogether, 10 animals ( 6 males and 4 females) were captured on 51 occasions (including 41 recaptures). Additionally, on ten occasions trapped animals managed to escape from their traps. The captured polecats were anaesthetized (with Combelen, $0.1 \mathrm{ml}$ per $1 \mathrm{~kg}$ body mass) and marked with incisions on the upper part of the ear.

In 1990 and 1991, three adult polecats ( 2 males, 1 female) were radio-collared, but one male immediately disappeared from the study area and the female lost her transmitter soon after she had been collared. One individual was radio-tracked during the following periods: $6-17$ Feb., $24-25$ Nov., and $28-29$ Dec. 1990, and $12-18$ Jan. 1991 (19 days, including a total of 31 continuous observations lasting from $45 \mathrm{~min}$ to $13 \mathrm{~h}$ ). The position of the polecat (when inactive) and routes of its movements were mapped.

A total of 94 polecats ( 57 males, 33 females, 4 of unknown sex) was caught by farmers in the village of Białowieża in $1960-1976,1982,1985$, and 1990. Farmers trapped polecats as pests usually after these predators had caused damage to poultry or rabbits. Some of the fresh polecat carcasses were then brought to the Mammal Research Institute, which has been locally known for its collection of skulls of wild mammals. At the M.R.I. the carcasses were weighed and measured. The sex and age of polecats were determined. Some individuals were delivered without pelts, so the body masses of these polecats were excluded from the analysis.

\section{Results}

\section{Winter ecology of polecats in the Bialowieża National Park}

Information on polecats captured on a $4.5-\mathrm{km}$ stretch of Orłówka stream in the Białowieża National Park is given in Table 1. The minimum time of inhabiting the river by individual polecats calculated as the time from the first to the last capture varied from 1 to 342 days. Four out of 6 males were present on the stream for a very short time (less than 3 weeks) and were classified as transients (Table 1). Two males (Nos 1 and 24) stayed in the study area for a long time (over 3 months) and were treated as residents. All 4 females lived on Orłówka stream for at least 4 weeks and were classified as residents. 
Table 1. Data on polecats Mustela putorius captured on a 4.5-km stretch of Orłówka stream in the Białowieża National Park in the winters of $1988 / 89$ - 1990/91. Residents - polecats present in the study area $>3$ weeks, transients $-<3$ weeks.

\begin{tabular}{|c|c|c|c|c|c|c|}
\hline No. & Sex & $\begin{array}{l}\text { Body } \\
\text { mass } \\
(\mathrm{g})\end{array}$ & $\begin{array}{c}\text { Total } \\
\text { number } \\
\text { of captures }\end{array}$ & $\begin{array}{c}\text { First and last } \\
\text { dates } \\
\text { of capture }\end{array}$ & $\begin{array}{l}\text { Minimum } \\
\text { residency } \\
\text { time (days) }\end{array}$ & Status \\
\hline \multirow[t]{2}{*}{1} & M & $?$ & 3 & 28 Jan - 12 Mar 89 & 44 & resident \\
\hline & & & 4 & $14-24$ Dec 89 & $11^{1}$ & resident \\
\hline 3 & M & 750 & 3 & $15-31$ Dec 89 & 17 & transient \\
\hline 11 & M & $?$ & 2 & $16-24$ Dec 89 & 9 & transient \\
\hline 13 & M & 1400 & $1^{2}$ & 10 Apr 90 & 1 & transient \\
\hline 16 & M & $?$ & 2 & $4-5$ Jan 89 & 2 & transient \\
\hline \multirow[t]{2}{*}{24} & M & 750 & 5 & 6 Feb -6 Mar 90 & 28 & resident \\
\hline & & & 5 & 23 Nov $90-13$ Jan 91 & $54^{3}$ & resident \\
\hline 2 & $\mathrm{~F}$ & $?$ & 3 & 4 Jan - 14 Mar 89 & 70 & resident \\
\hline 4 & $\mathrm{~F}$ & $400-500$ & 9 & 17 Dec $90-20$ Mar 91 & 94 & resident \\
\hline 9 & $\mathrm{~F}$ & $450-600$ & 11 & 11 Jan - 22 Mar 91 & 71 & resident \\
\hline 18 & $\mathrm{~F}$ & $?$ & 3 & $4-29$ Jan 89 & $26^{4}$ & resident \\
\hline
\end{tabular}

${ }^{1}$ assuming the continuous presence of male No. 1 , it resided for a total of 330 days;

${ }^{2}$ found dead in Białowieża village in early May 1990;

${ }^{3}$ radiotracked for 5 days after the last capture (not included in the minimum residency time); assuming the continuous presence of male No. 24, it resided for a total of 342 days;

${ }^{4}$ probably escaped from the trap during the trapping conducted on the 41 st day after the last capture. If so, the minimum residency time would be 67 days.

During 3 consecutive winters, 4,5 and 3 polecats were captured along Orłówka stream. Only two males (No. 1 and No. 24) inhabited the stream area during two consecutive winters (Table 1). The turnover of polecats was very high; most individuals were recorded only during one winter and none persisted on the river for longer than two years.

In the winters of $1988 / 89$ and 1990/91, Orłówka stream was inhabited by 2 resident females and 1 resident male (Table 1 ). In the winter of 1989/90, no females were recorded. Two males (Nos 3 and 11), captured in December 1989 inhabited the stream for 17 and 9 days, respectively. At the same time, male No. 1, which had been first recorded in the previous winter, was replaced by a new resident, male No. 24 (Fig. 1). Two other males (Nos 13 and 16) were trapped during one trapping session only. Male No. 13 was found dead in the village, about $4.5 \mathrm{~km}$ from the capture site on Orłówka stream, at the beginning of May 1990.

The numbers of resident and transient polecats differed between winters (Fig. 1). However, the maximum number of polecats recorded at any time along the stream was 3 during all winters. The average maximum density of polecats recorded concurrently along Orłówka stream was $0.7 \mathrm{inds} / 1 \mathrm{~km}$ of the watercourse.

Home ranges of resident polecats, estimated linearly along the stream and delimited by the extreme capture points for each specimen (plus the $1 / 2$ distance 


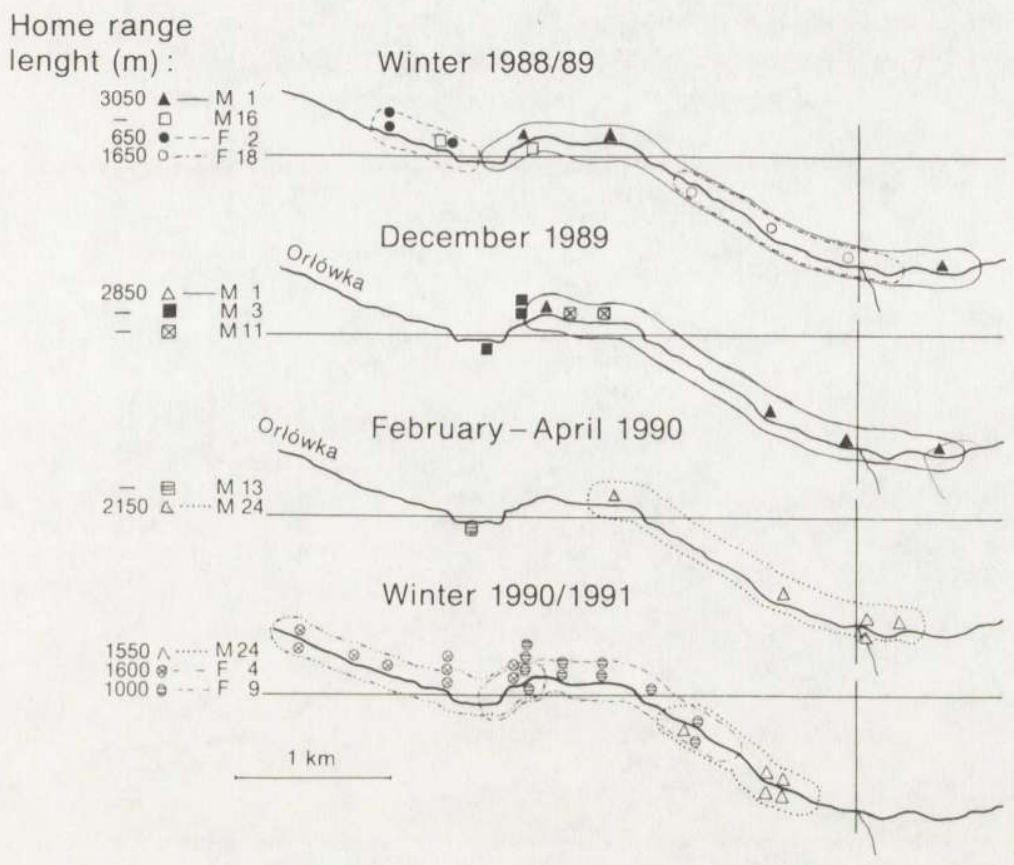

Fig. 1. Home ranges of resident polecats and places of capture of transients along Orłówka stream in the Białowieża National Park from 1988/89 to 90/91. Symbols - places of captures, lines - home range boundaries. Home range sizes of resident polecats measured linearly along the Orłówka stream (the distance between the 2 farthest points of captures increased by the $1 / 2$ distance between the nearest traps on each end of the home ranges). See Table 1 for detailed data on the trapped polecats.

between the nearest traps on each end of the home range), varied from $1,000 \mathrm{~m}$ to $3,500 \mathrm{~m}$ in males, and from $650 \mathrm{~m}$ to $1,650 \mathrm{~m}$ in females (Fig. 1). Home ranges of both resident males (Nos 1 and 24) were situated in the same, central and upper stretch of the stream. All transient males were captured either on peripheries of the home ranges of residents, or outside their ranges (Fig. 1).

During both winters, the females' home ranges were nearly exclusive. Home ranges of females Nos 2 and 18 did not overlap each other (Fig. 1). The common part of the home ranges of neighbouring females Nos 4 and 9 covered about 25\% of each female's range. By contrast, the home range of resident male No. 1 completely overlapped female No. 18's home range, but merely adjoined female No. 2's range (Fig. 1). The home range of male No. 24 overlapped nearly $70 \%$ of female No. 9's range (if a male's range was estimated by radiotracking, comp. Fig. 2 ) or $30 \%$ of it (if the trapping method is used, see Fig. 1).

The radiotelemetry of male No. 24 showed that this individual penetrated mainly the surroundings of the stream, but sometimes it moved as far as about $1,300 \mathrm{~m}$ from Orłówka (Fig. 2). However, the movements to places away from Orłówka stream were also undertaken along the small water course and bog alderwoods. During 15 out of $19(79 \%)$ days of radiotracking, the polecat moved 


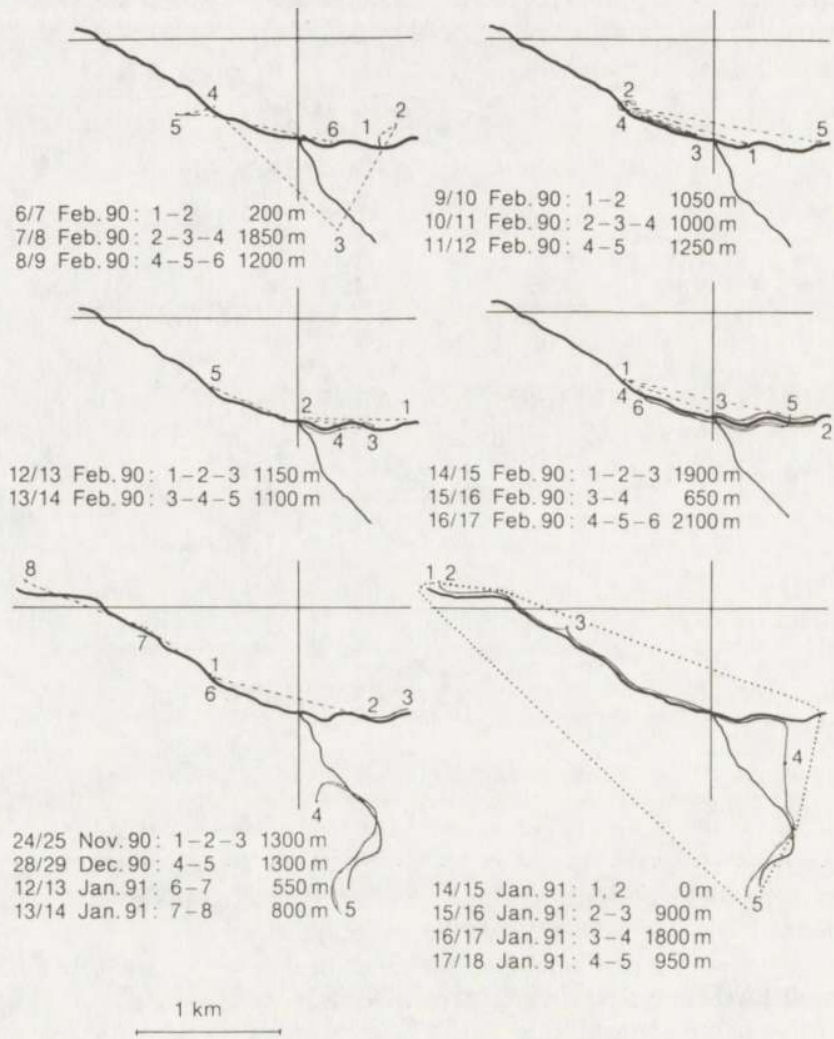

Fig. 2. Home range use and daily movement distances of resident male polecat (No. 24) on Orłówka stream in the winters of $1989 / 90$ and $1990 / 91$ - data from radiotracking (continuous line - real movement routes, broken line - straight line distance between two consecutive localisations). The home range size ( $200 \mathrm{ha}$, dotted line) estimated by the method of minimum convex polygon.

in the immediate vicinity of Orłówka. On 4 days (21\%), the polecat was found further than $200 \mathrm{~m}$ from the stream. The size of its home range estimated by the method of minimum convex polygon was 200 ha $\left(2 \mathrm{~km}^{2}\right)$ (Fig. 2).

On Orłówka stream the polecat was usually moving from one end of its home range to another (Fig. 2). The average distance of daily movement, calculated from 19 days of radio-tracking and measured in a straight line, was $1,100 \mathrm{~m}$ (SD 550 $\mathrm{m}$, range $0-2,100 \mathrm{~m})$. Altogether, 8 dens of polecat No. 24 were found. One of them was used 5 times, while all others were used only once. In one of them the polecat stayed continuously for more than $24 \mathrm{~h}$. Five dens were dug under the roots of large living trees (alder, linden, hornbeam, ash), and three dens were located under the roots or logs of fallen trees. The dens were located from 0.5 to $200 \mathrm{~m}$ (on average $50 \mathrm{~m}$ ) from the water course. 


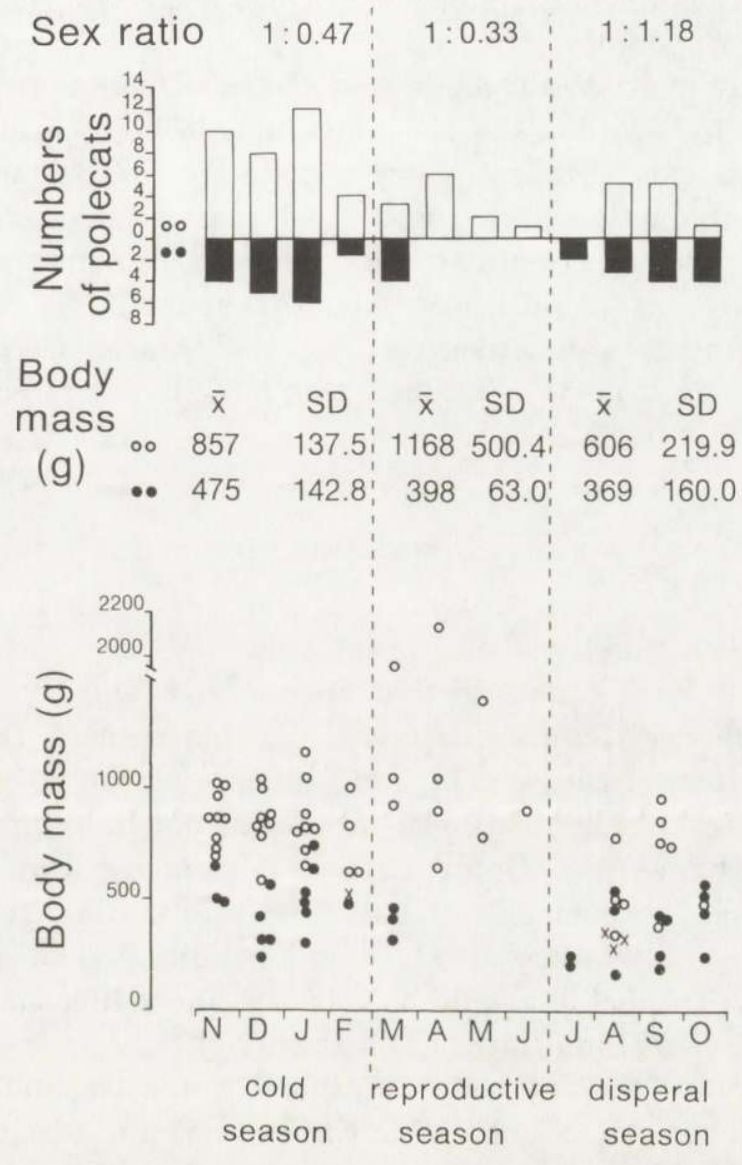

Fig. 3. Numbers and body masses of polecats captured in the village of Białowieża. Data pooled for 1960 - 90. Sample sizes vary because body masses of few polecats were not available and the sex of some polecats (marked $x$ on the lower figure) was not identified. $O$ - males, - - females.

\section{Polecats caught in the village of Bialowieża}

The entire sample ( 94 polecats trapped) was divided into 3 seasonal groups, which reflected the seasonal cycle in polecat biology: 'cold season' (November February), 'reproductive season' (March - June), and 'dispersal season' (July October).

The number of polecats captured in the village in the three seasons is shown in Fig. 3. Most of the individuals (54\%) were trapped in the 'cold season', and the least $(17 \%)$ were captured in the 'reproductive season' $(\mathrm{G}=20.12, p<0.001)$.

Males were trapped more often than were the females; the sex ratio of the entire sample was $1.7: 1(\mathrm{G}=6.48, p<0.02)$. The seasonal variation of the sex 
ratio of captured polecats was recorded. Males dominated most in the reproductive season (1:0.33) and cold season (1:0.47). In contrary, during dispersion females were slightly more frequently captured (1:1.18).

The average body mass of all males was $854 \mathrm{~g}$ (SD 310.2, $\mathrm{n}=50$ ) and that of females $423 \mathrm{~g}$ (SD 150.7, $\mathrm{n}=31$ ). The individuals of both sexes captured in the dispersal season had the smallest average body mass. The largest males were captured in the reproduction period and the largest females in the cold season (Fig. 3). For both males and females the seasonal differences in the body mass were significant (males: 'cold' vs. 'dispersal' season $\mathrm{U}_{\mathrm{s}}=264, p<0.01$, Mann-Whitney U-test; 'reproductive' vs. 'dispersal' season $\mathrm{U}_{\mathrm{s}}=100, p<0.001$; 'cold' vs. 'reproductive' season $\mathrm{U}_{\mathrm{s}}=208.5, p<0.05$; females: 'cold' vs. 'dispersal' season $\left.\mathrm{U}_{\mathrm{s}}=135.5, p<0.05\right)$.

\section{Discussion}

In mild winters (such as those during the study period) polecats inhabiting the Białowieża National Park maintain and obviously defend their clearly defined home ranges, which are sexually exclusive. In this respect, they resemble the typical mustelid pattern (Erlinge 1974, King 1975, review in Powell 1979). 'Linear' home ranges of polecats resemble those of other semiaquatic predators, the river otter and mink (Erlinge 1968, Gerell 1970). Male ranges were twice as long as female ranges, which is supposed to result from well marked sexual dimorphism (Powell 1979, Moors and Lavers 1981, Blandford 1987). The quick turnover of polecats on Orłówka probably resulted from the short life span of this species reported by Walton (1977) and Moors and Lavers (1981).

All data about polecat spacing behaviour, home range use, and daily movements presented in this paper reflect good winter conditions and territorial rather than nomadic spacing. The linear home ranges cannot be directly compared to the literature about polecat ranges. Our radio-tracked polecat occupied the home range of $200 \mathrm{ha}$ (minimum convex polygon method) or $1-2 \mathrm{~km}$ (linear estimation). Since this male's range was of average range size of all captured polecats, it seems that they are similar to those reported from Russia $(100-2,500$ ha, Danilov and Rusakov 1969), Sweden (20 - 90 ha, Nilsson 1978), Great Britain (100.8 ha on average, Blandford 1987) and Switzerland (8.5 - 1,100 ha, Weber 1989b). The lengths of daily movements of a radio-tracked male were within the distances recorded for polecats by Lodé (1988) and Weber (1989b). However, Blandford (1987) and Danilov and Rusakov (1969, data from snow-tracking) reported much longer daily movement distances of polecats (up to $8 \mathrm{~km}$ ).

Severe winter conditions deprive polecats of their defendable resources and make them nomadic. Nomadism of polecats was reported by Weber (1989a, b), who related it to the scarcity of food resources (anurans). The appearance of three transient males on Orłówka stream coincided with the coolest and most snowy 
periods in the winters of $1988 / 89$ and $1989 / 90$. The exchange of resident males in the winter of $1989 / 90$ suggests that some of the nomadic polecats may be successful in establishing new home ranges. Nomadism forced by severe winter conditions was the most likely reason for the highest numbers of polecats caught in winter in the village of Białowież. These numbers were highest in January, which is the coldest month of the year in Białowieża. It is worth noting, that in winter both males and females were frequently trapped in the village, although males predominated.

Domestic animals and other human food sources attract polecats to settlements in winter (Weber 1989c). Kossak (1989) described an arrival of a polecat in her yard (an isolated forest lodge adjoining the Białowieża National Park) during the severe winter of $1985 / 86$. The polecat established its den $8 \mathrm{~m}$ away from the carcasses of two roe deer fawns that were laid in the yard. The polecat fed on the carcass for 2 weeks and then left the yard. In the winter of $1987 / 88$, Dr. S. Kossak (pers. comm.) noticed another polecat den in her barn. A few polecat scats that were collected at that den, contained exclusively the remains of rabbits kept in the yard.

In spring, the nomadism of polecats has different implications than in winter. Among polecats trapped in the village during the mating season, i.e. in March and April, males predominated and the appearance of very large males was recorded. Most probably, they moved around to search for receptive females. Such a mating strategy was described for the polecat by Weber (1989b) and for the stoat Mustela erminea by Erlinge and Sandell (1986).

Winter feeding ranges of polecats (streams, bog alderwoods) are not homogenously distributed in the forest. The habitable patches may be so small that they support few individuals and may not even contain any females (see winter 1989/90 on Orłówka stream; Fig. 1). Therefore, the male's nomadism would be the only chance to take part in reproduction. Nomadism of males as a mating strategy may be a common pattern of spacing of mammalian predators in spring (see review in Sandell 1989).

During reproduction, females are sedentary. They were nearly absent from the summer data in Białowieża village. However, a few breeding females lived in the village, despite severe persecution by farmers. In the summer of 1991 , a female polecat leading her 4 kittens across the street in the village was observed $(\mathrm{H}$. Zdanowicz, pers. comm.).

The small body weight of polecats captured in the village from July to October suggests that most of them were the young of that year dispersing from their natal range, although some of them might have been adult females in very poor postbreeding condition (compare Weber 1992). The equal numbers of males and females in this subsample corroborates the suggestion that the real sex ratio in polecats is 1:1 (Moors and Lavers 1981), whereas the frequently recorded predominance of males in mustelid populations results from behavioural differences between sexes and sexual dimorphism (Blandford 1987, Buskirk and Lindstedt 1989). 
The results of our studies suggest that the polecats' living in association with man observed throughout Europe (review in Blandford 1987) could develop on the basis of polecats' adaptation to the seasonal shifting from territorial spacing to nomadism. In pristine forests, these shifts occur from wet to drier habitats (Jędrzejewski et al., in prep.). The large-scale drainage and land reclamation projects all over Europe caused the disappearance of wet habitats and deprived polecats of their ancestral living conditions. Human settlements with clumps of vulnerable domestic animals became an attractive, though risky, alternative to these predators, more and more so as the pristine habitats shrank and deteriorated.

Acknowledgements: We thank Earthwatch Research Corps for their help with capturing and radio-collaring of polecats. The study was supported by Earthwatch and partly by CPBP 04.10 grants. We are grateful to Prof. Dr. Z. Pucek for his permission to use the collection of trapped polecats. Drs J. Goszczyński, Z. Pucek, and D. Weber kindly commented on the earlier draft and E. McNeish corrected the English usage. We are grateful to Dr. K. C. Walton for his review.

\section{References}

Blandford P. R. S. 1987. Biology of the polecat Mustela putorius: a literature review. Mammal Rev. 17: $155-198$.

Buchalczyk T. 1981. Order: Carnivores - Carnivora. [In: Keys to vertebrates of Poland. Mammals. Z. Pucek, ed.]. PWN - Polish Scientific Publishers, Warszawa: 260 - 306.

Buchalczyk T. 1983. Mustela putorius Linnaeus, 1758. [In: Atlas of Polish Mammals, Z. Pucek and J. Raczyński, eds]. PWN - Polish Scientific Publishers, Warszawa: 149 (map) and 154 - 156 (text).

Buskirk W. S. and Lindstedt S. L. 1989. Sex biases in the trapped samples of Mustelidae. J. Mammal. 70: $88-97$.

Danilov P. I. and Rusakov O. S. 1969. Peculiarities of the ecology of Mustela putorius in north-west districts of the European part of the USSR. Zool. Zhurn. 48: 1383 - 1394. [In Russian with English summary]

Erlinge S. 1968. Territoriality of the otter, Lutra lutra L. Oikos 19: $81-88$.

Erlinge S. 1974. Distribution, territoriality and numbers of the weasel Mustela nivalis in relation to prey abundance. Oikos 25: $308-314$.

Erlinge S. and Sandell M. 1986. Seasonal changes in the social organization of male stoats, Mustela erminea: an effect of shifts between two decisive resources. Oikos 47: $57-62$.

Ewer R. F. 1973. The carnivores. Cornell Univ. Press, Ithaca, New York. I-XVI + $1-494$.

Faliński J. B. 1986. Vegetation dynamics in temperate lowland primeval forest. Dr. W. Junk Publishers, Dordrecht. Geobotany 8: 1-537.

Gerell R. 1970. Home ranges and movements of the mink Mustela vison Schreber in southern Sweden. Oikos 21: $160-173$.

Herrenschmidt V. 1982. Note sur les déplacements et le rythme d'activité d'un Putois Mustela putorius suivi par radiotracking. Mammalia 46: $554-556$.

Jensen A. and Jensen B. 1972. Ilderen (Putorius putorius) og Ilderjadten i Danmark 1969/70. Danske Vildundersogelser 18: $1-32$.

Jędrzejewski W., Jędrzejewska B. and Szymura A. 1989. Food niche overlaps in a winter community of predators in the Białowieża Primeval Forest, Poland. Acta theriol. 34: 487 - 496.

Jędrzejewski W. and Jędrzejewska B. 1992. Food and foraging habits of the red fox Vulpes vulpes in relation to variable food resources in the Białowieża National Park, Poland. Ecography 15: $213-221$. 
Jędrzejewski W., Jędrzejewska B., Okarma H. and Ruprecht A. L. 1992. Wolf predation and snow cover as mortality factors in the ungulate community of the Białowieza National Park, Poland. Oecologia (Berl.) 90: $27-36$.

Kalela O. 1948. Changes in the distribution of the polecat in Finland. Suomen Riista 2: 93 - 96.

King C. M. 1975. The home range of the weasel Mustela nivalis in an English woodland. J. anim. Ecol. 44: $639-668$.

Kossak S. 1989. Multiple hunting by lynx and red fox and utilization of prey by some carnivores. Acta theriol. 34: $505-512$.

Langley P. J. and Yalden P. W. 1977. The decline of rarer carnivores in Great Britain during the 19th century. Mammal Rev. 7: $95-116$.

Libois R. M. 1984. Atlas des mammiferes sauvages de Wallonie (suite) - La genre Mustela en Belgique. Cahiers Ethol. appl. 4: 279-314.

Lodé T. 1988. Note préliminaire sur la biologie du comportement du Putois (Mustela putorius L. 1766) dans les bocages humides de l'Ouest de la France. Bull. Soc. Sc. Nat. Ouest France, Museum Nantes 10 (2): $58-67$.

Mermod C., Debrot S., Marchesi P. and Weber J. M. 1983. Le putois Mustela putorius L. en Suisse romande. Rev. Suisse Zool. 90: 847 - 856 .

Moors P. J. and Lavers R. B. 1981. Movements and home range of ferrets Mustela furo at Pukepuke Lagoon, New Zealand. New Zeal. J. Zool. 8: 413 - 424.

Nilsson T. 1978. Home range utilisation and movements in polecat, Mustela putorius, during autumn. Congress Theriol. Int., Brno, CSSR. Abstracts, p. 13.

Olszewski J. L. 1986. Rola ekosystemów lesnych w modyfikacji klimatu lokalnego Puszczy Białowieskiej. Wyd. PAN (Prace habilitacyjne), Ossolineum, Wrocław: $1-222$.

Powell R. A. 1979. Mustelid spacing patterns: variations on a theme by Mustela. Z. Tierpsych. 50: $153-165$.

Sandell M. 1989. The mating tactics and spacing patterns of solitary carnivores. [In: Carnivore behaviour, ecology and evolution, J. L. Gittleman, ed.]. Chapman and Hall, London: $164-182$.

Santos-Reis M. 1983. Status and distribution of the Portugese mustelids. Acta Zool. fenn. 174: $213-216$

Skarén O. 1979. Polecats of Finland. Suomen Luonto 38: $33-36$.

Walton K. C. 1970. The polecat in Wales. Welsh Wildlife Trust. (Ed. W. S. Lacey). North Wales Naturalists Trust, Bangor.

Walton K. C. 1977. Polecat. [In: The handbook of British mammals. G. B. Corbett and H. N. Southern, eds]. 2nd ed. Blackwell Sci. Publishers, Oxford: $345-352$.

Weber D. 1988. Die aktuelle Verbreitung des Iltisses Mustela putorius in der Schweiz. Rev. Suisse Zool. 95: 1041 - 1056.

Weber D. 1989a. The ecological significance of resting sites and the seasonal habitat change in polecats Mustela putorius. J. Zool., Lond. 217: 629 - 638.

Weber D. 1989b. Beobachtungen zu Aktivität und Raumnutzung beim Iltis (Mustela putorius L.). Rev. Suisse Zool. 96: $841-862$.

Weber D. 1989c. The diet of polecats (Mustela putorius) in Switzerland. Z. Säugetierk. 54: 157 - 171.

Weber D. 1992. Einige Daten zu Grösse und Kondition schweizerischer Iltisse Mustela putorius L. Säugetierk. Mitteil. 34: 1 - 9.

Received 10 April 1992, accepted 26 May 1992. 